University of Nebraska - Lincoln

DigitalCommons@University of Nebraska - Lincoln

$8-2000$

\title{
Effects of Water Conditions on Clutch Size, Egg Volume, and Hatchling Mass of Mallards and Gadwalls in the Prairie Pothole Region
}

\author{
Pamela Pietz \\ USGS Northern Prairie Wildlife Research Center, ppietz@usgs.gov \\ Gary Krapu \\ USGS Northern Prairie Wildlife Research Center, gkrapu@usgs.gov \\ Deborah Buhl \\ USGS Northern Prairie Wildlife Research Center, dbuhl@usgs.gov \\ David A. Brandt \\ USGS Northern Prairie Wildlife Research Center, dbrandt@usgs.gov
}

Follow this and additional works at: https://digitalcommons.unl.edu/usgsnpwrc

Part of the Other International and Area Studies Commons

Pietz, Pamela; Krapu, Gary; Buhl, Deborah; and Brandt, David A., "Effects of Water Conditions on Clutch Size, Egg Volume, and Hatchling Mass of Mallards and Gadwalls in the Prairie Pothole Region" (2000). USGS Northern Prairie Wildlife Research Center. 61.

https://digitalcommons.unl.edu/usgsnpwrc/61

This Article is brought to you for free and open access by the US Geological Survey at DigitalCommons@University of Nebraska - Lincoln. It has been accepted for inclusion in USGS Northern Prairie Wildlife Research Center by an authorized administrator of DigitalCommons@University of Nebraska - Lincoln. 
(July-August, 2000)

\title{
EFFECTS OF WATER CONDITIONS ON CLUTCH SIZE, EGG VOLUME, AND HATCHLING MASS OF MALLARDS AND GADWALLS IN THE PRAIRIE POTHOLE REGION ${ }^{1}$
}

\author{
Pamela J. Pietz, Gary L. Krapu, Deborah A. Buhl and David A. Brandt \\ U.S. Geological Survey, Northern Prairie Wildlife Research Center, 8711 37th Street S.E., \\ Jamestown, ND 58401,e-mail: pam_pietz@usgs.gov
}

\begin{abstract}
We examined the relationship between local water conditions (measured as the percent of total area of basins covered by water) and clutch size, egg volume, and hatchling mass of Mallards (Anas platyrhynchos) and Gadwalls (A. strepera) on four study sites in the Prairie Pothole Region of North Dakota and Minnesota, 1988-1994. We also examined the relationship between pond density and clutch size of Mallards and Gadwalls, using data collected at another North Dakota site, 1966-1981. For Mallards, we found no relationships to be significant. For Gadwalls, clutch size increased with percent basin area wet and pond density; hatchling mass marginally increased with percent basin area wet. These species differences may reflect, in part, that Mallards acquire lipid reserves used to produce early clutches before they reach the breeding grounds, whereas Gadwalls acquire lipid reserves locally; thus Gadwall clutches are more likely to be influenced by local food resources.
\end{abstract}

Key words: Anas platyrhynchos, Anas strepera, clutch size, duckling mass, egg size, Prairie Pothole Region, water conditions.

The Prairie Pothole Region (PPR), a primary breeding area for North American dabbling ducks (Anderson and Henny 1972), is characterized by an abundance of small, shallow wetlands with dynamic hydroperiods. When these wetland basins reflood following seasonal drawdown or drought, production of aquatic invertebrates increases sharply (Euliss et al. 1999). Aquatic invertebrates are a major component of the diet of female dabbling ducks during egg production (Krapu and Reinecke 1992). If food availability influences clutch or egg size of wild dabbling ducks in the PPR, the effect may be reflected by water conditions in this highly dynamic landscape.

During 1988-1994, water conditions varied from extremely dry to extremely wet on areas where we were studying breeding ecology of Mallards (Anas platyrhynchos) and Gadwalls (A. strepera) in the PPR. We used this opportunity to examine relationships between water conditions and clutch size, egg volume, and hatchling body mass (a surrogate for egg size) for these

\footnotetext{
${ }^{1}$ Received 22 December 1999. Accepted 17 July 2000.
}

two common species of dabbling ducks. We also examined the relationship between water conditions and clutch size for these species in data collected by other researchers during 1966-1981 in the PPR.

\section{METHODS}

\section{STUDY SITES AND DATA COLLECTION}

We measured clutch size, egg volume, and hatchling mass at three study sites in North Dakota and one (for Mallards only) in western Minnesota. We collected data at each study site for 2-6 years (Table 1). All study sites were within the PPR. North Dakota study sites were $14 \mathrm{~km}$ south of Kulm $\left(46^{\circ} 12^{\prime} \mathrm{N}, 98^{\circ} 53^{\prime} \mathrm{W}\right)$ in Dickey County, $27 \mathrm{~km}$ north of Jamestown $\left(47^{\circ} 11^{\prime} \mathrm{N}, 98^{\circ} 40^{\prime} \mathrm{W}\right)$ in Stutsman County, and on the Koenig Wildlife Development Area $\left(47^{\circ} 23^{\prime} \mathrm{N}\right.$, $100^{\circ} 49^{\prime} \mathrm{W}$ ) in McLean County. The Minnesota study site was $32 \mathrm{~km}$ northwest of Detroit Lakes $\left(46^{\circ} 59^{\prime} \mathrm{N}\right.$, $96^{\circ} 12^{\prime} \mathrm{W}$ ). Vegetative cover and wetland types on the Kulm, Jamestown, and Detroit Lakes study sites were described by Cowardin et al. (1998). The Koenig study site, about $62 \mathrm{~km}^{2}$ in size, was composed of roughly $40 \%$ seeded grasslands, $30 \%$ native prairie, and $10 \%$ wetland basins.

Nest searching was conducted in perennial cover on public lands (mostly federally owned Waterfowl Production Areas) and some private lands from late April or early May until mid- to late July. Methods for finding and marking nests, recording nest data, and candling eggs followed Klett et al. (1986). Eggs were candled to determine incubation stage; nests were revisited at roughly 2 -week intervals. Clutch size was recorded as the maximum number of eggs found in completed clutches. Nest-initiation dates were estimated from information collected on clutch size and incubation stage when the nest was first found. Length and width of each egg were measured to the nearest $0.1 \mathrm{~mm}$, and egg volume was calculated using Hoyt's (1979) shape constant in the formula: Volume = 0.515 (length)(width) ${ }^{2}$. Mean egg volume was calculated for each full clutch where all eggs were measured. At a subset of these nests and at some additional nests, we weighed newly hatched ducklings to the nearest 0.5 g. Mean hatchling body mass was calculated for each nest at which three or more ducklings were weighed. For nests at which all eggs and at least three ducklings were measured, we verified that mean egg volume and mean hatchling mass were highly correlated (Mallards: 
TABLE 1. Number of years and number of nests per year (range) for which Mallard and Gadwall clutch size, mean egg volume, and mean hatchling mass were measured at four study sites in North Dakota and Minnesota, $1988-1994$.

\begin{tabular}{|c|c|c|c|c|c|c|}
\hline \multirow[b]{2}{*}{ Study Site } & \multicolumn{2}{|c|}{ Clutch size } & \multicolumn{2}{|c|}{ Mean egg volume } & \multicolumn{2}{|c|}{ Mean hatchling mass } \\
\hline & Mallard & Gadwall & Mallard & Gadwall & Mallard & Gadwall \\
\hline \multicolumn{7}{|l|}{ Detroit Lakes, MN } \\
\hline No. years (1988-1991) & 4 & & 4 & & 2 & \\
\hline No. nests & $7-26$ & & $6-8$ & & $4-6$ & \\
\hline \multicolumn{7}{|l|}{ Kulm, ND } \\
\hline No. years (1988-1994) & 6 & 6 & 6 & 2 & 5 & 5 \\
\hline No. nests & $5-44$ & $12-50$ & $5-33$ & $47-48$ & $4-13$ & $6-20$ \\
\hline \multicolumn{7}{|l|}{ Jamestown, ND } \\
\hline No. years (1988-1994) & 6 & 6 & 5 & 2 & 4 & 5 \\
\hline No. nests & $6-39$ & $19-60$ & $6-34$ & $19-49$ & $2-12$ & $10-17$ \\
\hline \multicolumn{7}{|l|}{ Koenig, ND } \\
\hline No. years (1992-1993) & 2 & 2 & 2 & 2 & 2 & 2 \\
\hline No. nests & $10-27$ & $52-96$ & $8-23$ & $50-89$ & $2-7$ & $21-28$ \\
\hline Total nests & 327 & 578 & 201 & 302 & 83 & 170 \\
\hline
\end{tabular}

$r=0.73, n=80, P<0.001 ;$ Gadwalls: $r=0.80, n$ $=109, P<0.001)$.

We evaluated water conditions on the study sites as described in Krapu et al. (2000), using aerial videography, National Wetlands Inventory maps, and GIS methodologies developed by Cowardin et al. (1988). We used all temporary, seasonal, and semipermanent wetland basins within each study site to calculate water conditions. Percent basin area wet (total area of basins that was covered by water/total area of basins on the study site) was used as the index of water conditions for each site in each year (hereafter "site-year"). Inundated portions of wetland basins were delineated using aerial videography taken in June of each year. Although May water conditions would have been preferable for analyzing Mallard reproductive variables, only June videography was available for 1992-1994, and we found that May and June water conditions were highly correlated in the years when both were available ( $r=0.97$ for 12 site-years).

As an additional test of the relationship between clutch size and water conditions, we analyzed a set of data collected by other researchers (Higgins et al 1992) during 1966-1981 on Mallard and Gadwall nests at Northern Prairie Wildlife Research Center's Woodworth Field Station $\left(47^{\circ} 8^{\prime} \mathrm{N}, 9^{\circ} 15^{\prime} \mathrm{W}\right)$ in North Dakota. Vegetative cover, wetlands, and other attributes of the Woodworth Field Station were described by Higgins et al. (1992). Pond density in May was used as an index of water conditions; measures of basin area wet were not available for this site. Pond density was defined as the number of basins per $\mathrm{km}^{2}$ containing water in May.

\section{STATISTICAL ANALYSES}

Before we could test for relationships between reproductive measures and water conditions, we had to examine the relationship of each reproductive measure to nest-initiation date. We regressed the reproductive measure on nest-initiation date for each site-year and tested the hypothesis that all site-year slopes were equal to zero (Littell et al. 1996). The hypothesis was rejected if the reproductive measure varied with date for at least one site-year.

Clutch size varied with nest-initiation date for at least one site-year for both species (Mallards, $F_{18291}=$ 7.4, $P<0.001$; Gadwalls, $\left.F_{14,550}=24.6, P<0.001\right)$. When site-years were combined, clutch size declined with nesting date for Mallards $(\mathrm{y}=0.041 \mathrm{x}+14.71)$ and Gadwalls $(\mathrm{y}=0.081 \mathrm{x}+22.00)$. For Mallards, mean egg volume varied with nesting date for at least one site-year $\left(F_{17,167}=2.1, P<0.01\right)$, although the slope was significantly different from zero for only 2 of 17 site-years. We detected no relationship between mean egg volume and nesting date for Gadwalls $\left(F_{6,290}\right.$ $=1.5, P=0.17$ ), or between mean hatchling mass and nesting date for either species (Mallards, $F_{13,57}=$ $0.2, P>0.99$; Gadwalls, $F_{12,146}=1.1, P=0.40$ ). For data collected at the Woodworth Field Station, clutch size declined with nest-initiation date for both Mallards $\left(F_{16,222}=5.2, P<0.001\right)$ and Gadwalls $\left(F_{16,434}\right.$ $=21.2, \stackrel{P}{P}<0.001)$.

We could not include nest-initiation date and water conditions in the same model (e.g., ANCOVA) because nesting date and water conditions were not independent and were measured at different levels (water condition was calculated for each site-year; nest-initiation date and reproductive measures were calculated for each nest). Thus, for any reproductive measure that varied with nesting date for at least one site-year, we examined the relationship between that measure and water conditions at three specific dates, representing early, middle, and late nest initiations for that species during the years of data collection. We calculated the predicted value of the reproductive measure and its variance from the regression model of the reproductive measure and nest-initiation date in each site-year (Lit- 


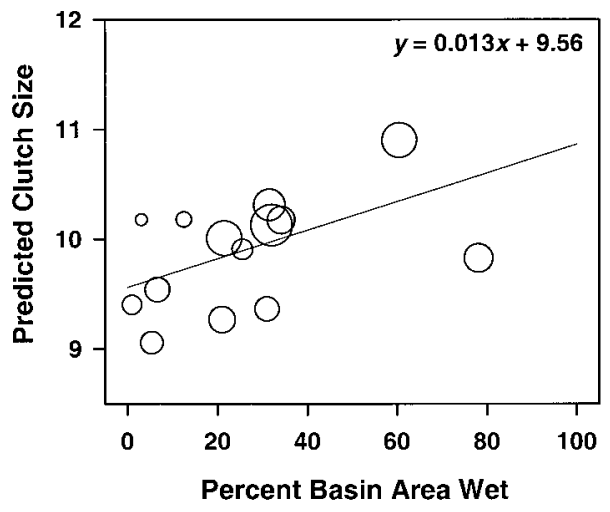

FIGURE 1. Clutch size of Gadwalls in relation to water conditions (percent of total basin area that was covered by water in June) predicted for median nestinitiation dates in 14 site-years. Each circle represents the predicted clutch size for a given study site and year; area of each circle is inversely proportional to the variance of the predicted clutch size (i.e., larger circles indicate greater precision). Line represents slope of the relationship.

tell et al. 1996). Because variances of these predicted values were not equal, the predicted value for each site-year was weighted by the inverse of its estimated variance (Neter et al. 1990). We then used weighted regression analysis to look for a linear relationship between water conditions (i.e., percent of the total basin area covered by water or, for Woodworth, pond density) and the predicted site-year values of the reproductive measure. A separate regression was conducted for early, middle, and late nesting dates. The three dates we used coincided with the first three quartiles from the overall data set $(25 \%, 50 \%, 75 \%$ of all nests): 28 April, 10 May, and 28 May for Mallards and 21 May, 28 May, and 5 June for Gadwalls. For analyses of data from the Woodworth Field Station, these dates were 17 May, 1 June, and 12 June for Mallards and 30 May, 8 June, and 20 June for Gadwalls. High predation rates and lack of predator exclosures on the Woodworth site resulted in later average initiation dates for nests found at Woodworth.

For reproductive measures that did not vary with nesting date $(P>0.05)$, we calculated the mean value of that measure for each site-year. We then used weighted regression analysis to look for a linear relationship between water conditions and the mean siteyear values of the reproductive measure. In these analyses, each mean value was weighted by the number of nests in the site-year sample. General linear models (GLM) procedure of SAS (SAS Institute Inc. 1989) was used to conduct all regressions.

\section{RESULTS}

For Mallards, we detected no linear relationships between the percent of total basin area that was covered by water and the clutch size predicted for either 28 April, 10 May, or 28 May (all $F_{1,16}<0.1, P>0.8$ ). For Gadwalls, we found positive linear relationships

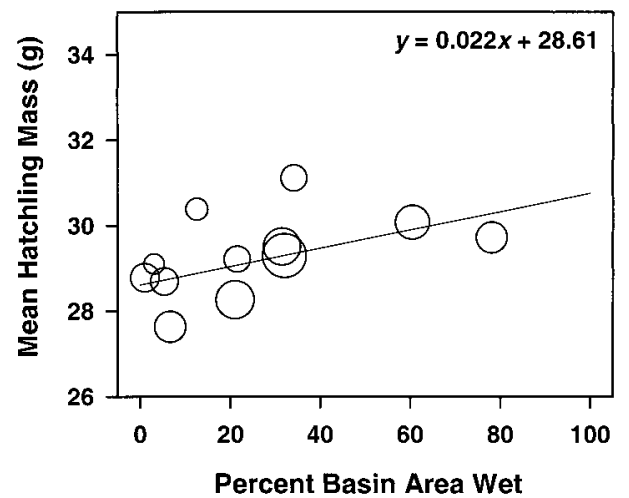

FIGURE 2. Hatchling mass (g) of Gadwalls in relation to water conditions (percent of total basin area that was covered by water in June) in 12 site-years. Each circle represents mean hatchling mass for a given study site and year; area of each circle is proportional to the number of nests in the sample. Line represents slope of the relationship.

between percent basin area wet and the clutch size predicted for 21 May $\left(F_{1,12}=7.1, P=0.02\right)$ and 28 May $\left(F_{1.12}=5.0, P<0.05\right.$; Fig. 1$)$, and a marginal relationship for 5 June $\left(F_{1,12}=3.6, P=0.08\right)$. The slopes $( \pm \mathrm{SE})$ of the regressions for Gadwalls were similar for all three dates $(0.014 \pm 0.005,0.013 \pm$ 0.006 , and $0.013 \pm 0.007$, respectively), translating to an additional 1.1 eggs per clutch over the range of water conditions observed (1-78\% basin area wet).

For Mallards, we detected no linear relationships between the percent of total basin area that was covered by water and the mean egg volume predicted for 28 April, 10 May, or 28 May (all $F_{1,15}=1.0-2.0, P=$ $0.17-0.33$ ), or between mean hatchling mass and percent basin area wet $\left(F_{1,11}=0.1, P=0.78\right)$. For Gadwalls, no linear relationship was evident between mean egg volume and percent basin area wet $\left(F_{1,4}<0.1, P\right.$ $=0.90)$; however, the ability to detect a relationship may have been limited by the small number of siteyears $(n=6)$. Mean hatchling mass for Gadwalls was marginally related to percent basin area wet $\left(F_{1,10}=\right.$ $4.4, P=0.06$; Fig. 2). The slope of the regression was $0.022 \pm 0.010$, which results in a $1.7-\mathrm{g}$ difference in mean hatchling mass over the range of water conditions observed (1-78\% basin area wet).

For data collected at the Woodworth Field Station, 1966-1981, we detected no linear relationships between pond density and Mallard clutch size predicted for 17 May, 1 June, or 12 June (all $F_{1,14} \leq 1.2, P \geq$ 0.29 ). For Gadwalls, however, we found positive linear relationships between pond density and predicted clutch size for all three dates: 30 May $\left(F_{1,14}=14.4, P\right.$ $=0.002), 8$ June $\left(F_{1.14}=13.3, P=0.003\right.$; Fig. 3$)$, and 20 June $\left(F_{1,14}=8.0, P=0.01\right)$. The slopes of the regressions for Gadwalls were $0.033 \pm 0.009,0.043$ \pm 0.012 , and $0.046 \pm 0.016$ for the three dates, respectively. This translates to an additional $1.2-1.6$ eggs per clutch over the range of pond densities that occurred (3.5-38.7 ponds $\mathrm{km}^{-2}$ ) in this 16-year period. 


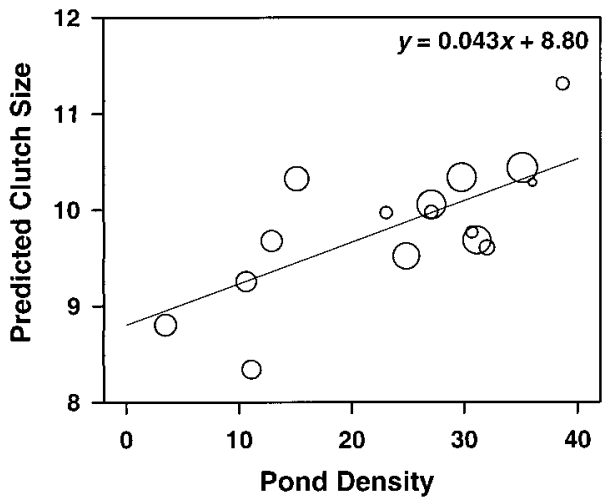

FIGURE 3. Clutch size of Gadwalls in relation to density of ponds in May at Woodworth Field Station, ND, 1966-1981, predicted for median nest-initiation dates in 16 years. Each circle represents the predicted clutch size for a given year; area of each circle is inversely proportional to the variance of the predicted clutch size (i.e., larger circles indicate greater precision). Line represents slope of the relationship.

\section{DISCUSSION}

When considering responsiveness to water conditions across years, it should be noted that Mallards (Krapu et al. 1983, Cowardin et al. 1985) and probably Gadwalls (Lokemoen et al. 1990) respond primarily by initiating more nests during wet years than dry years. Our data suggest that, for those females that do nest, clutch size also changes with water conditions for Gadwalls but not for Mallards.

The species difference in clutch-size response may reflect the fact that Mallards initiate nesting several weeks earlier than Gadwalls (Higgins et al. 1992 Greenwood et al. 1995) and acquire lipid reserves used in production of early clutches prior to arrival on the breeding grounds (Krapu 1981). In contrast, female Gadwalls spend several weeks on the breeding grounds and gain lipid reserves locally before initiating nesting (G. Krapu, unpubl. data). Thus, Gadwall clutches are more likely to be influenced by local food availability and, consequently, water conditions on the breeding grounds.

It is unclear why Mallard clutch size did not respond to water conditions late in the nesting season, after females had exhausted the lipid reserves they carried to the breeding grounds. One factor that may obscure trends between clutch size and water conditions is the likelihood that more young birds nest when conditions are wet. Young female dabbling ducks tend to lay smaller clutches than older females (Dane 1965, Krapu and Doty 1979, Duncan 1987) and start nesting later, so an increased proportion of young birds in the sample can be expected to decrease the mean values for clutch size, especially in mid-to-late season. Thus, whatever positive trend exists between clutch size and water conditions must more than compensate for the negative trend linked to age in order to be detected Another possibility is that those Mallards that continue to nest in drier years obtain sufficient nutrients to maintain clutch size, even when aquatic foods are scarce, by out-competing other dabbling ducks for the best feeding habitats (Bailey and Batt 1974) or by foraging in a wider variety of habitats.

Low variability in size of eggs laid by individual females has been demonstrated for captive Mallards (Batt and Prince 1979); however, Mallard egg size still responds in part to food availability (Eldridge and Krapu 1988, Pehrsson 1991). The lack of response to water conditions we observed in Mallard egg size and (the related variable) hatchling mass may be explained by the same factors described for clutch size above. In Gadwalls, the lack of egg size response to water conditions appears to contradict the marginal response of hatchling mass. However, we had data on Gadwall hatchling mass for 12 site-years and on egg size for only 6 site-years; the egg sample may have been insufficient to detect an effect on a characteristic with relatively low variability. In any case, the response seen in hatchling mass may not have been large enough to affect duckling survival. The difference in predicted hatchling mass between the wettest and driest site-years was only about $6 \%$ of the overall mean mass (29.2 g). Rhymer (1988) found that hatchling mass of captive Mallards affected cold tolerance. However, a $6 \%$ difference may be negligible, especially given that most Gadwall ducklings (unlike those of early-nesting Mallards) are reared in the warmest months of the year.

The increase of 1-2 eggs per Gadwall clutch $(\bar{x}=$ 9.9 eggs) estimated to occur across the range of water conditions we observed may be large enough to affect overall productivity of a population. Using their generalized waterfowl population model, Johnson et al. (1992) demonstrated that clutch size has more influence on productivity of species with higher nest success. For Mallards in the PPR, they found that the influence of clutch size on productivity was relatively low. The importance of clutch size to Gadwall productivity in the PPR should be higher, however, because Gadwalls generally have higher nest success than Mallards (Klett et al. 1988). If a population or productivity model were developed for Gadwalls in the PPR, our results suggest that the accuracy of the model would be improved by including the effect of water conditions on clutch size.

We are grateful to the Central Flyway Council for providing financial support during 1988-1991, and to personnel at the Arrowwood, Detroit Lakes, and Kulm Wetland Management Districts of the U.S. Fish and Wildlife Service for allowing use of their facilities and access to lands under their management. We also appreciate the cooperation of numerous landowners and operators for allowing access to their properties. We especially thank N. E. Drilling, C. P. Dwyer, R. J. Greenwood, D. W. Howerter, W. F. Jensen, J. T. Lokemoen, C. R. Luna, M. A. Sovada, A. B. Sargeant, and their crews for finding nests and collecting field data. We thank L. M. Cowardin and H. T. Sklebar for collecting and interpreting data on wetland conditions. J. A. Beiser, W. E. Newton, and G. A. Sargeant provided statistical advice. C. D. Ankney, R. R. Cox Jr., N. H. Euliss Jr., P. L. Flint, D. H. Johnson, and three 
anonymous reviewers provided helpful comments on earlier drafts of this paper.

\section{LITERATURE CITED}

Anderson, D. R., AND C. J. Henny. 1972. Population ecology of the Mallard. I. A review of previous studies and the distribution and migration from breeding areas. U.S. Fish and Wildl. Serv. Resource Publ. 105, Washington, DC.

BaILEy, R. O., AND B. D. J. Batt. 1974. Hierarchy of waterfowl feeding with Whistling Swans. Auk 91: 488-493.

BAtT, B. D. J., AND H. H. PRince. 1979. Laying dates, clutch size and egg weight of captive Mallards. Condor 81:35-41.

Cowardin, L. M., P. M. Arnold, T. L. Shaffer, H. R. Pywell, AND L. D. Miller. 1988. Duck numbers estimated from ground counts, MOSS map data, and aerial video, p. 205-219. In J. D. Scurry [ED.], Proc. 5th natl. MOSS users workshop. Louisiana Sea Grant College Program, Baton Rouge, LA, and U.S. Fish and Wildlife Service, Slidell, LA.

Cowardin, L. M., D. S. Gilmer, ANd C. W. Shaiffer. 1985. Mallard recruitment in the agricultural environment of North Dakota. Wildl. Monogr. 92.

Cowardin, L. M., P. J. Pietz, J. T. LoKemoen, H. T. Sklebar, and G. A. Sargeant. 1998. Response of nesting ducks to predator exclosures and water conditions during drought. J. Wildl. Manage. 62: 152-163.

DANE, C. W. 1965. The influence of age on the development and reproductive capability of the Bluewinged Teal (Anas discors Linnaeus). Ph.D. diss., Purdue Univ., Lafayette, IN.

Duncan, D. C. 1987. Nesting of Northern Pintails in Alberta: laying date, clutch size, and renesting. Can. J. Zool. 65:234-246.

EldRIDGE, J. L., AND G. L. KRAPU. 1988. The influence of diet quality on clutch size and laying pattern in Mallards. Auk 105:102-110.

Euliss, N. H., JR., D. A. WRUblesKi, AND D. M. MushET. 1999. Wetlands of the Prairie Pothole Region: invertebrate species composition, ecology, and management, p. 471-514. In D. P. Batzer, R. B. Rader, and S. A. Wissinger [EDS.], Invertebrates in freshwater wetlands of North America: ecology and management. John Wiley and Sons, New York.

Greenwood, R. J., A. B. Sargeant, D. H. Johnson, L. M. Cowardin, AND T. L. ShafFer. 1995. Factors associated with duck nest success in the Prairie Pothole Region of Canada. Wildl. Monogr. 128.

Higgins, K. F., L. M. Kirsch, A. T. Klett, and H. W. MiLler. 1992. Waterfowl production on the Woodworth Station in south-central North Dakota,
1965-1981. U.S. Fish and Wildl. Serv. Resource Publ. 180, Washington, DC.

HoYT, D. F. 1979. Practical methods of estimating volume and fresh weight of bird eggs. Auk 96:7377.

Johnson, D. H., J. D. Nichols, and M. D. SchwartZ. 1992. Population dynamics of breeding waterfowl, p. 446-485. In B. D. J. Batt, A. D. Afton, M. G. Anderson, C. D. Ankney, D. H. Johnson, J. A. Kadlec, and G. L. Krapu [EDS.], Ecology and management of breeding waterfowl. Univ. Minnesota Press, Minneapolis, MN.

Klett, A. T., H. F. Duebbert, C. A. FaAnes, and K. F. Higgins. 1986. Techniques for studying nest success of ducks in upland habitats in the Prairie Pothole Region. U.S. Fish and Wildl. Serv. Resource Publ. 158, Washington, DC.

Klett, A. T., T. L. Shaffer, and D. H. Johnson. 1988. Duck nest success in the Prairie Pothole Region. J. Wildl. Manage. 52:431-440.

Krapu, G. L. 1981. The role of nutrient reserves in Mallard reproduction. Auk 98:29-38.

Krapu, G. L., AND H. A. Doty. 1979. Age-related aspects of Mallard reproduction. Wildfowl 30:3539.

Krapu, G. L., A. T. Klett, and D. G. Jorde. 1983. The effect of variable spring water conditions on Mallard reproduction. Auk 100:689-698.

Krapu, G. L., P. J. Pietz, D. A. Brandt, and R. R. Cox JR. 2000. Factors limiting Mallard brood survival in prairie pothole landscapes. J. Wildl. Manage. 64:553-561.

Krapu, G. L., and K. J. ReINECKE. 1992. Foraging ecology and nutrition, p. 1-29. In B. D. J. Batt, A. D. Afton, M. G. Anderson, C. D. Ankney, D. H. Johnson, J. A. Kadlec, and G. L. Krapu [EDS.], Ecology and management of breeding waterfowl. Univ. Minnesota Press, Minneapolis, MN.

Littell, R. C., G. A. Milliken, W. W. Stroup, and R. D. Wolfinger. 1996. SAS system for mixed models. SAS Institute, Inc., Cary, NC.

Lokemoen, J. T., H. F. Duebbert, and D. E. Sharp. 1990. Homing and reproductive habits of Mallards, Gadwalls, and Blue-winged Teal. Wildl. Monogr. 106.

Neter, J., W. Wasserman, AND M. H. Kutner. 1990. Applied linear statistical models: regression, analysis of variance, and experimental designs. 3rd ed. Richard D. Irwin, Homewood, IL.

Pehrsson, O. 1991. Egg and clutch size in the Mallard as related to food quality. Can. J. Zool. 69:156162.

RHYMER, J. M. 1988. The effect of egg size variability on thermoregulation on Mallard (Anas platyrhynchos) offspring and its implications for survival. Oecologia 75:20-24.

SAS InSTITUTE INC. 1989. SAS/STAT user's guide. Version 6, 4th ed. Vol. 2. SAS Institute, Inc., Cary, $\mathrm{NC}$. 